\title{
143．能動運動における重心動摇検査
}

\author{
岡田行弘・斉藤 晶 高橋正紘・神崎 仁(慶大)
}

目的従来の反射系に上る起立制御の他に，複数の 感賞入力による空間認知に基づく予测的な起立制御を 評価するため，能動運動中の重心動摇の大きさを测定 した。またこの結果加ら, 視覚, 前庭, 足底加らの感 覚入力が起立の予測的制御において果たす役割を考察 することを目的とした。

対象 健常者 6 名（男性 3 名，女性 3 名，平均年齢 29.3歳).

万法開閉眼で各々, 単脚, マン, 閉脚, 開脚の異 なる支持面積に際して能動運動時の重心移動を重心動 摇計アニマグラビコーダーG1810にて記録した。能動 運動估，静止，前後左右方向への頭部傾斜，左右振り 返り，及び前困を行った。別に，開閉眼，各足底条件 て，前後左右各方向にできる限り重心を移動させた際 の重心移動を各方向の許容幅として記録した。

結果 移動軌跡加方, 左右, 前後方向の重心移動幅 を計測した。この移動幅と許容幅との比を制御の精度 とした，左右方向の移動幅は，開眼で比較的小さく保 たれた，開脚では開閉眼の影響は，ほとんど認められ ず，単脚ではすべての動作で開閉眼の平均值に有意差
を認めた。閉眼では，足底条件が制限され身体の移動 を伴う動作孛行うと移動軌跡の輻は急激に増大した。 この傾向は, 前後方向では明らかでなかったが, 左右 方向の制丳の精度ではさらに顕著であった。

考察 起立維持のために，身体の移動が大きくなる 程前庭入力の必要性は堌加し，マン，単脚等では制限 された足底入力をより活用しなければならないと考え られる。このような条件で，視賞入力の影犁がより大 きく現れたことより，視覚入力は，前庭や足底加らの 入力を十分に活用するために不可欠で，視覚によって 周囲の静止した空間を認知し，この認知に前庭および 足底加らの自己の運動に関する情報を加えて起立制御 が達成されると考えられた。質問 松永 花(奈良 医大). どの種類の能動運動が臨床上一番簡便に用いら れると思うか。応答 我々の目的は前庭視觉固有 受容器等がどの上うな入力を得てそいをどのように起 立制御に用いているかを知ることである。徉って現段 階では動作の条件を減らすことは，まだ難しいと考之 る.

\section{4. 水平性衝動性眼球運動の最高速度の検討}

\author{
小川真滋・山田 理 中島幹夫・生駒尚秋（鳥取大）
}

目的水平性衝動性眼球運動（水平性サッケード） の最高速度は脸幹・特に橋の障害で低下したという報 告が多々，䛦断的重要性は高い。水平性サッタードの 最高速度は指標振幅に依存するとされているが，定量 分析による正常様態の検討は現時点ではまだ十分とは いえない，今回われわれは，健康成人において水平性 サッケードの最高速度が指標振幅の変化によりどのよ うに変化するか定量的に分析した。さらに温度眼振 桧查により反射性に解発した前庭性眼振急速相の最高 速度との比較を行い，両者の差について強討を加えた。

万法 対象は, 神経耳科学的に異常を認めない10代 〜30代までの若年健康成人 30 名とした。水平性サッケ
ードの誘発には眼球運動誘発措置 (永島, $\mathrm{KN}-52$ ) を 用々, 視標跳躍頻度 $0.3 \mathrm{~Hz}$ の水平二点交互刺激を行 い, 視標振幅を $10^{\circ}, 20^{\circ}, 30^{\circ}$ と変化させた。温度眼振急 速相は暗所開眼下に $4{ }^{\circ} \mathrm{CO}$ 冷水 $20 \mathrm{ml}$ を 10 秒間で注水 し誘発した。記録には直流増幅器 (三栄測器, 1117B) と ENG(三栄測器, 124A) を, 電極は三好式亜鉛電極 を使用した。右方㧍よび左方眼球運動で最高速度の平 均值と標準誤差学求めた。

結果 1 水平性サッケードと温度眼振急速相とも に振幅の増大により最高速度は有意に増加した。 2 同一振幅では，水平性サッヶードは温度眼振急速相上 も最高速度が有意に大きかった。

\section{5.コンピュータを使用した滑動性眼球運動の}

$$
\text { 定量化システム }
$$

佐久間惊・加藤 功・岩澤 寛 高橋䜾子・荻野貞雄・竹山 勇 (聖マリアンナ大)

目的 彷来の滑動性眼球運動の分析方法で, 周波数, 振幅, 予測性に依存し, 正確に滑動性眼球運動を 
定是することはできなかつた，昨年，我々はRashbass の示した不連続な動き(step) 刺激・緩徐な動き(ramp) 刺激をランダムに制御し，これにより open loop conditionによる滑動性眼球運動刺激装置を開発した。し かし，定量化するにあたり，原波形の平滑化と眼球速 度・眼球加速度の算定をしなけ机ばならず，コンピュ 一タの導入が必要となった。そこで，今回我々はでき るだけ㲸用性を持たせるため，一般に市販されている 製品を組み合わせ，原波形の平滑化と眼球速度・眼球 速度の算定を行うシステムを導入したのでここに報 告する。

法リアルタイムでデジタル変換できるシグナル プロセッサ（カノープス電子社製 ASIP - 0260）とA/ $\mathrm{D}$ コンバータ（カノーブス電子社製 $\mathrm{ADX} 98 \mathrm{E}$ )を介す ることで, 電気眼振計に直結したパーソナルコンピュ ータ（NEC 社製 PC9801）にデータを入力した。電気 眼振計は皿電極を使用し， DCで記録，A/D 変換は 12bit, サンプリングタイムは $200 \mathrm{~Hz}$ で行った. 波形処 理ソフト（カノープス電子社製 wave master II) によ りバイナリファイルを作成し、フロッピーディスク上 に記録した，記録されたデータは，MS-DOS 版 Nss (86) BASICによる自作プログラムを用いて波形の平 滑化及び微分化を高速で処理，演算処理後の波形と数 值をXYプロッタとCRTディスプレイ画面上に出力
した。

結果 健康正常人に対し右 $3^{\circ}$ の step $12^{\circ} / \mathrm{S}^{2}$ back ward の ramp 刺激を加えた結果, 刺激後約 $80 \mathrm{~ms}$ の潜 時で滑動性眼球運動の開始が見られた。

まとめこのシステムを使用することによって，眼 球運動の原波形加ら眼球速度・眼球加速度が算定でき ることとなった。また市販の製品を使用しているので システムの構築が容易であるばかりでなく，プグラ 么を書き換えることによって温度眼振拈 $\mathrm{OKN}$ の分析 ができるなど汎用性に富んでいる特長を有している， しかしその半面ノイズ処理が不完全, 使用プログラム による計算能力の限界，波形の記録と分析がオフライ ンであるため即座に分析結果が得られない欠点があ る. 今後, 滑動性眼球運動の加趃的変化などの分析に もこのシステムは寄与することと思われる。質問 大橋直樹(富山医薬大)。オープンループとは何を意味 するか。応答 Rashbassのステップ刺激により 網膜上に視標のズレをつくりた゚し，ズレが確認さ机補 正されることにより，Close となる、ズレをつづけるよ うに再刺激を加えると，open loopが持続される。 質問 羽柴基之(名市大) . parafoveal の刺激を使用し た理由。応答 step 刺激により, pursuit をより長 く持続させることが可能となるので, pursuit の細かい 観察ができる。

\section{6. 前庭性眼振および視運動性眼振の緩徐相と 急速相の関連性について}

\section{渡辺行雄 - 大村明彦 - 伊東宗治 - 将積日出夫 - 水越鉄理（富山医薬大）}

目的 眼振急速相は振幅と速度との関係を主体に研 究が行われてきたが, 前庭性眼振, 視運動性眼振 (OKN) の急速相が緩徐相側の条件とどのような関係 にあるかはこ机まで明確ではなかった。今回，私達注 正常例の両眼振反応の緩徐相上急速相の関連を明確に し，その臨床応用の可能性について検討を加えた。

方法 1 . 刺激：前庭性刺激住振幅 $\pm 120^{\circ}, 0.1 \mathrm{~Hz}$ の振子様回転とした。視運動刺激は投影型加速度刺激 (加速度 $1^{\circ} \mathrm{deg} / \mathrm{sec}^{2}, 100$ 秒間) とし，視標として臨床に 使用されている視角 $2^{\circ}$ で30間隔に配置された線条 と，被険者の全視野が刺激される上うに考慮した直径 $5 \mathrm{~mm}$ から $20 \mathrm{~mm}$ の無数の小円を不規則に投影するラ ンダム刺激の 2 種類とし，視標の差異による反応の差 についても検討の対象とした２．分析：22名の正常 被検者について，コンピュータにより各眼振反応中の 全眼振による緩徐相, 急速相の振幅一振幅, 振幅一速 度, 速度一速度間の相関係数を計算し, 眼振反応の緩 徐相と急速相の相関性を蚞討した。

結果 結論 1 . 前庭性眼振: 緩徐相と急速相の各 パラメー夕は高い相関性を示し, 前庭性眼振では急速 相が緩徐相の反応態度に一致して発現することが確認
された２．ランダム OKN：前庭性眼振と同様, 緩徐 相と急速相の高い相関性を示し，全視野刺激 OKN の 急速相発現が前庭性眼振と類似した発現機序に制御さ れることを示唆する所見であった。 3 . 線条刺激 OKN：急速相が緩徐相と相関性を示さない眼振と, 前 庭性眼振，ランダム OKN と同樣の高い相関性を示す 眼振の 2 様の眼振が発現していた。この傾向は梘標速 度が低速の部分で明確であるが，高速では差が不明確 であった，線条刺激における緩徐相と急速相の相関性 のない眼振群は等間隔の視標線条を捕捉 注視する中 心窩型眼振を，また，相関性の高い眼振群は網膜上の 刺激が優位となる，いわ和網膜型眼振を表している ものと考えら机た。また，椎骨脳底動脈循環不全症な どの中枢性平衡障害症例では, 線条 OKN で緩徐相速 度, 眼振数は正常でありながら, 緩徐相と急速相の相 関性のない眼振がほとんど見られない症例があった。

質問 羽柴基之(名市大). VBI の症例で pursuit は正 常であったか。応答 smooth pursuit は正常であ った。本症例では視運動刺激下における視標捕捉か障 害されたものと考えられた。 